Journal

of Geography

Politics and Society

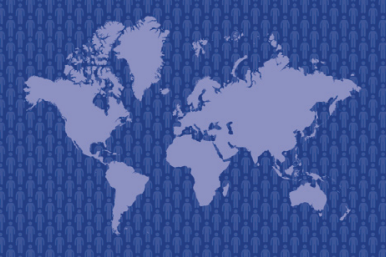

$9(2) / 2019$

\section{Journal of Geography, Politics and Society}

$2019,9(2), 10-19$

https://doi.org/10.26881/jpgs.2019.2.02

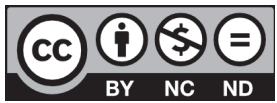

\title{
SIMILARITIES AND DIFFERENCES IN CHANGING NPS MARKET BROUGHT BY NEW REGULATORY APPROACHES IN SELECTED EASTERN AND CENTRAL EUROPEAN STATES WITH MOSTLY FOCUS ON POLAND AND LATVIA
}

\author{
Artur Malczewski (1), Agnese Zïle-Veisberga (2) \\ (1) National Bureau for Drug Prevention, Reitox Focal Point EMCDDA, 52/54 Dereniowa, 02-776 Warsaw, Poland, \\ e-mail: artur.malczewski@kbpn.gov.pl (corresponding author) \\ (2) Agnese Zile-Veisberga Sectoral Policy Department Ministry of the Interior of Latvia, Čiekurkalna 1.līnija 1 k-2, Riga, Latvia , \\ e-mail: agnese.veisberga@iem.gov.Iv
}

\section{Citation}

Malczewski A., Zïle-Veisberga A., 2019, Similarities and differences in changing NPS market brought by new regulatory approaches in selected Eastern and Central European states with mostly focus on Poland and Latvia, Journal of Geography, Politics and Society, 9(2), 10-19.

\begin{abstract}
The main objective of the paper is to explain, compare and conclude the effect on the new psychoactive substances (NPS) market brought by new and innovative responses to regulate the NPS (mostly between 2010 and 2014) in Estonia, Latvia, Lithuania, Poland, the Czech Republic, Hungary, and Romania. Countries where NPS problem reached the peak, the traditional response or simply substance scheduling did not work. Since the NPS do not fall under market regulations, also the response to the problem was innovative stepping out of the existing system (for example, temporary prohibition in Poland, Latvia). Moreover, a political and social pressure has been a factor to speed up the development of new regulations, sometime affecting the quality. Seemingly harsh sanctions and immediate reaction are main elements to close the NPS street shops. Meanwhile this approach hasn't caused a step back for chemical industry or science. Still is open question if national regulations against NPS market are fully enough. NPS market reacts very quickly for changing and only very strong and fast reaction from the institutional level seems to be effectiveness. Although NPS market differs in each country, study shows that harsh sanctions such as criminal liability and immediate reaction significantly decrease the availability of NPS, and thus contribute in decreasing acute health problems and prevalence. It was observed that at the time when stricter measure came into force, hospital emergencies were increased (Poland, Romania and in same extent Latvia).
\end{abstract}

\section{Key words}

New Psychoactive Substances, Law on New Psychoactive Substances, post-communist countries 


\section{Introduction}

The study focuses on various regulatory approaches introduced (mostly between 2010 and 2014) in Estonia, Latvia, Lithuania, Poland, Czech Republic, Hungary, and Romania, with a more in-depth research on situations in Latvia and Poland. The main objective is to explain, compare and conclude the effect on the new psychoactive substances (NPS) market brought by new and innovative responses to regulate the NPS. The first result of the study was presented on the annual conference of International Society for the Study of Drug Policy on May 2016 in Sydney. The subject of the study is the NPS market - a place where seller meets buyer and exchange their goods. To acknowledge the changes in the NPS market, different qualitative and quantitative data were used, e.g. NPS seizure data, data on hospital emergencies, surveys on prevalence, and interviews with field experts on demand and supply side and policy makers.

NPS became a major problem for the drug control systems as the NPS market was developing rapidly and offering increasingly more new substances. The number of NPS identified under the EU Early Warning System increased from 41 (in 2010) to 101 (in 2014) (European..., 2015 Monitoring Centre for Drugs and Drug Addiction, 2015). Moreover, the NPS sold might have contained other substances than the ones reported by the vendors (Brunt et al., 2017). Nearly all the countries which encountered the NPS problem introduced regulations aimed to delegalize such substances (New psychoactive..., 2016European Monitoring Centre for Drugs and Drug Addiction and Eurojust, 2016), except New Zealand, which legalized them for a short time (Rychert, Wilkins, 2015). Traditionally, the control systems which delegalized individual substances proved to be too slow and ineffective. Consequently, solutions intended to delegalize the whole groups of substances were introduced.

\section{Poland}

NPS were present on the Polish drug scene before 2008. As soon as by the end of 2008, 40 NPS shops were operational in the centres of major Polish cities offering an increasingly wide range of psychoactive products. NPS were arriving rapidly including synthetic cannabinoids, mephedrone and later on a whole range of cathinone-type substances. Businessmen who established the biggest legal highs retail chains promoted the trade on a franchise. NPS shops started springing up exponentially and soon, by the end of 2010, 1300 NPS shops (brick and mortar) were up and running across the country. The sale was conducted through both online and offline distribution channels with two arguably largest smart shop chains, i.e. 'dopalacze.com' (booster) and "smartshop', being the main competitors.

The first battery of actions resulted in controlling over 40 new substances under two consecutive amendments of the Drug Law in 2009-2010. The second amended came into force on 25 August 2010 and resulted in controlling mephedrone and mainly synthetic cannabinoids. On 4 March 2011, the Polish parliament adopted another amendment of the Drug Law, which controlled 23 new agents discovered in new psychoactive substances. Listing NPS is necessary, yet it is a passive and reactive way of responding to new threats.

The General Sanitary Inspector (GSI) was the direct operation against NPS street shops, which finally led to the closure or liquidation thereof on October 2010. The crackdown on NPS shops was necessitated by the growing number of NPS-related hospitalizations as well as media reports of several acute poisonings or even deaths caused by NPS. As of 3 October 2010, officers of the GSI accompanied by police officers closed down all NPS shops and NPS wholesale businesses (total of over 1300). A direct consequence of the operation was the elimination of NPS street shops.

According to the 2008 Youth Survey, NPS had ever been used by $4 \%$ while in 2010 this rate stood at $11 \%$. The Youth survey results from 2013 indicate a drop in the prevalence of NPS (5\%) (Malczewski, 2014). The 2013 measurement shows that the closure of the NPS shops had an impact on the consumption rates. The date from others surveys are presented on the figure 1 .

A different type of modification was introduced by the Amendment of 8 October 2010 of the Drug Law and Act on State Sanitary Inspection (SSI). It introduced a definition of NPS as a substitute drug. Such a drug is to be understood as any substances used instead of drug or for the same purposes as a drug, whose manufacture and placing on the market is not governed by separate regulations. In order to halt the further development of the supply of substitute drugs onto the Polish market, legislators focused on banning the manufacture of NPS and their introduction to trade. Whoever engages in the abovementioned activity shall be subject to a financial penalty between 5000 and 250000 EURO. At the same time, the enforcement of the regulations was vested in the SSI. According to the amended law, in the event of a reasonable suspicion that a product poses a threat to human health or life the SSI has the right to withdraw the product from the market for 


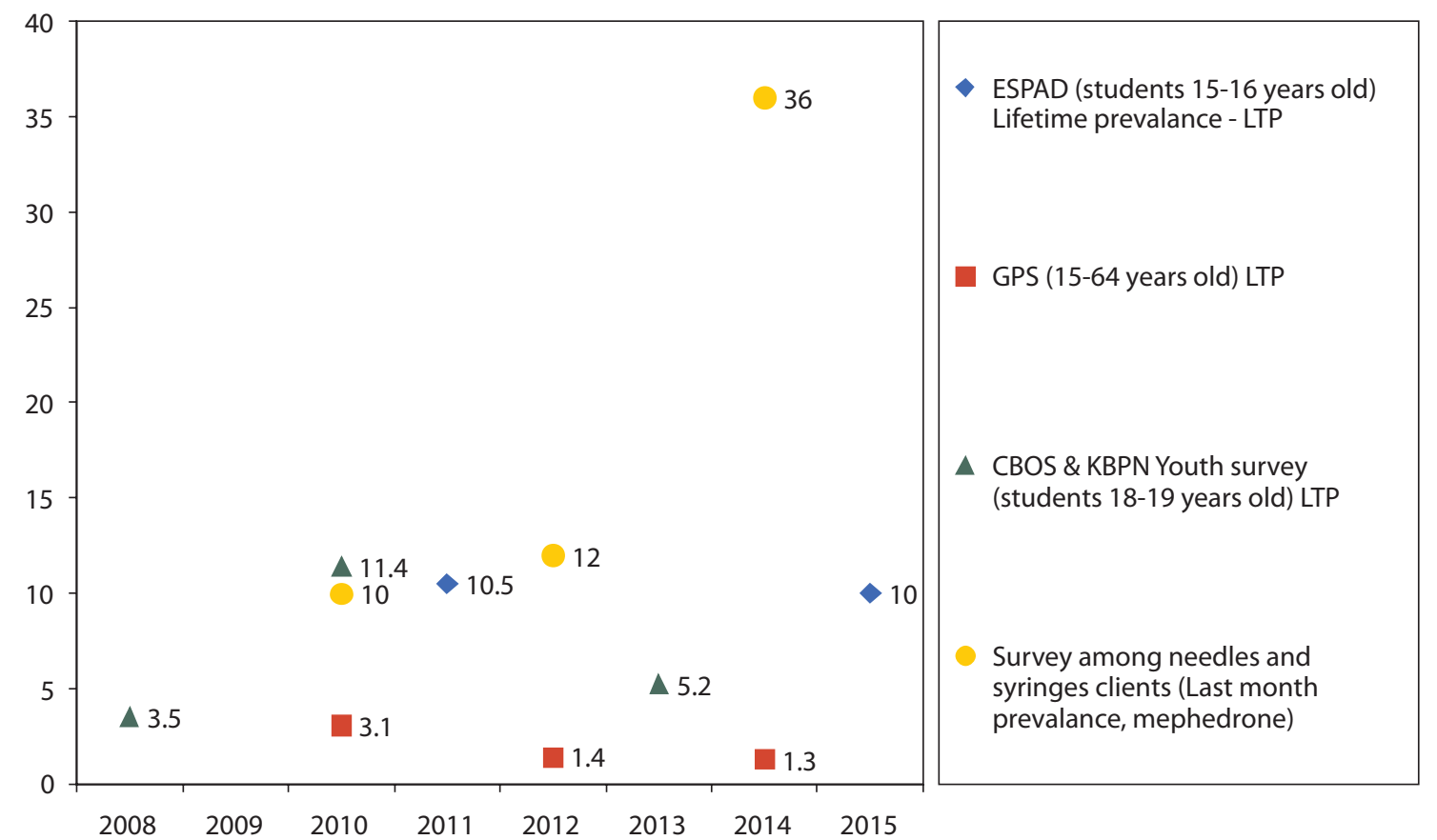

Fig. 1. Prevalence of NPS in general population and sub-populations, 2008-2015 (\%)

Source: Several sources was used for prepared figure: ESPAD: Sierosławski, 2015; GPS: Malczewski, Misiurek, 2015; CBOS \& KBPN Youth survey: Malczewski, 2015a; Survey among needles and syringes clients: Malczewski, 2016.

the period necessary to conduct an assessment and research into its safety. It is worth noting that the new law clearly targets individuals and entities introducing NPS to trade and not the consumers, who are treated more as victims of such practices.

The closure of street NPS shops gave rise to a fall in the NPS-related poisonings in 2011. According to the ESPAD surveys of 2011 and 2015 the percentage of NPS users remained at the same level of $10 \%$ LTP (age group 15-16) (Sierosławski, 2015). The NPS market started growing in 2012. In the end of 2012 the number of NPS-related poisonings started growing. The highest number was recorded in July 2015 (1966 cases) following the 1 July control of 114 NPS, which had been sold at high street shops and online (table 1). Similarly to previous years, NPS sellers made efforts to get ready for the criminalization. One of major NPS distributors had their products lab tested to ready for new Law changing. In previous years the controlled NPS were replaced with new ones. In the case of stimulant NPS the control of BZP in 2009 resulted in the arrival of mephedrone. After mephedrone was criminalized, MDPV started to be sold and then all kinds of synthetic cathinones such as penthedrone or alpha-PVP (Malczewski, 2015a). It is worth noting that similarly to 2010, when in October following the closure of NPS shops the highest number of NPS-related poisonings was recorded in July 2015 , in the subsequent months the number of poisonings began to fall (table 1 ).

The most prevalent NPS in 2014 were cathinones and synthetic cannabinoids: 3-MMC; ethcathinone; penthedrone; 3,4-DMMC; alpha-PVP; brephedrone; pMPPP as well as UR-144 and AM-2201 (Malczewski, Sałustowicz, 2015). The data on the table 2 showed that Polish NPS market seems to be one of the biggest in the region. In 2014, there were 100 smart shops operational in Poland (Malczewski, 2015b). The shops are being inspected and closed down by the SSI. However, some owners reopen them under

Tab. 1. Medical interventions due to overdoses of NPS in Poland (number of cases)

\begin{tabular}{|r|r|r|r|r|r|r|r|r|r|r|r|r|}
\hline year & I & II & III & IV & V & VI & VII & VIII & IX & X & XI & XII \\
\hline 2010 & & & & & & & 30 & 70 & 123 & 258 & 60 & 21 \\
\hline 2011 & 15 & 9 & 14 & 16 & 12 & 6 & 12 & 5 & 13 & 20 & 26 & 25 \\
\hline 2012 & 24 & 14 & 20 & 16 & 17 & 20 & 17 & 19 & 33 & 36 & 41 & 42 \\
\hline 2013 & 41 & 35 & 60 & 80 & 79 & 88 & 76 & 98 & 110 & 137 & 136 & 139 \\
\hline 2014 & 138 & 157 & 165 & 178 & 183 & 176 & 230 & 201 & 252 & 258 & 286 & 289 \\
\hline 2015 & 291 & 283 & 526 & 510 & 603 & 539 & 1966 & 661 & 449 & 761 & 528 & \\
\hline
\end{tabular}

Source: Burda, 2014, 2015. 
Tab. 2. The total number of NPS detected and reported to EMCDDA EWS in 2014 (samples)

\begin{tabular}{|l|c|c|c|c|c|}
\hline & 2010 & 2011 & 2012 & 2013 & 2014 \\
\hline Czechia & 120 & 23 & 26 & 57 & 33 \\
\hline Romania & 971 & 415 & 169 & 212 & 35 \\
\hline Hungary & 534 & 2335 & 2118 & 2538 & 5506 \\
\hline Poland & 241 & 762 & 1403 & 4061 & 5383 \\
\hline Lithuania & 0 & 0 & 62 & 78 & 132 \\
\hline Latvia & 133 & 142 & 289 & 819 & 889 \\
\hline Estonia & 0 & 70 & 105 & 98 & 134 \\
\hline
\end{tabular}

Source: Early Warning System Database of EMCDDA 2015.

different business names. The SSI imposed more than 3.5 millions EURO in 2014 worth of fines on NPS owners (GSI, 2016a). However, fines are hard to collect as the businesses often wind down once the SSI begins to look into their activities. In Poland, apart from NPS street shops there are over a dozen online stores where NPS can be purchased. Although SSI has made an effort to close the market since 2011 they were 170 NPS street shops in Poland in 2015 (GSI, 2016b). NPS are also selling by dealers.

\section{Latvia}

The spread of new psychoactive substances at larger extent started in 2008 when several stores selling smoking mixtures that contained synthetic cannabinoids opened. These NPS shops were closed when in 2009 in total 25 new substances were added to the list of controlled substances, however, it was not for a long time and in 2010/2011 new retail and internet shops selling NPS were opened.

According to the police data at the beginning of 2013 there were at around 70 selling places operating in Latvia. Moreover, in 2007 The Forensic department of the State Police, which in practice is the only institution performing expertises on seized drug in the country, performed 15 expertises of NPS, than in 2014 it performed 1387 expertises. Majority of seized NPS belonged to the group of synthetic cannabinoids - 91.8\% in 2014 (Sïle, 2015).

Moreover, results of sociological surveys also showed use of NPS in general population and high use in some sub-populations. In 2013, 38\% respondents of a study among people with high risk drug use confirmed that they had had bought these substances at least once in their lives. Surveys also showed high life-time prevalence among 15-16 years old students (11\% in 2011 and 15\% in 2015), young people (9\% in 2011 and 9\% in 2014), partygoers (18\%) and prisoners (18\%) (see fig. 2).
Although there were clear indication from treatment centres that intoxication and addiction from NPS is increasing noticeably, data to justify it are scarce. For example, there are some data available from years 2013 and 2014 from the Register of the Narcological patients (national coverage) showing that in 2013 in total 245 and in 2014307 had used NPS. In addition, in 2014, 416 drug overdose cases have been recorded, in which the patient has received inpatient care, in 2013 - 345 and in 2012 277 such cases were recorded. Peak in the data of 2014 can be explained with the "boom" in the use of NPS in Latvia (Pūgule et al., 2016).

Initially, government responded to this problem by simply listing substances in the list of controlled substances, as a result, by the end of 2013 in total 60 new substances had been added to the list (Sïle, 2015). However, by this time it had been acknowledged that simple listing system did not stop the emergence of NPS. For example, newly controlled substances were immediately replaced by new uncontrolled substances. Due to the high pressure of society, the aim the policy makers became a closure of the NPS market, therefore, new and innovative response. Then followed a line of amendment in legislation to find a proper system that could close NPS market, initially falling to reach their aims.

Currently there are two main elements in the legislation to control the emergence of NPS in the market:

- Substance control by a generic system was introduced in April 2013. In broad lines, it means that only basic formula of chemical group is listed, at the same time stating that every substance that falls under the particular group is also controlled. However, practice showed that market easily reacted to these changes and sellers found new substances that were not controlled by the generic system, and the list needed to be updated regularly. Besides it, in order to control new substances as soon as they appear on the 


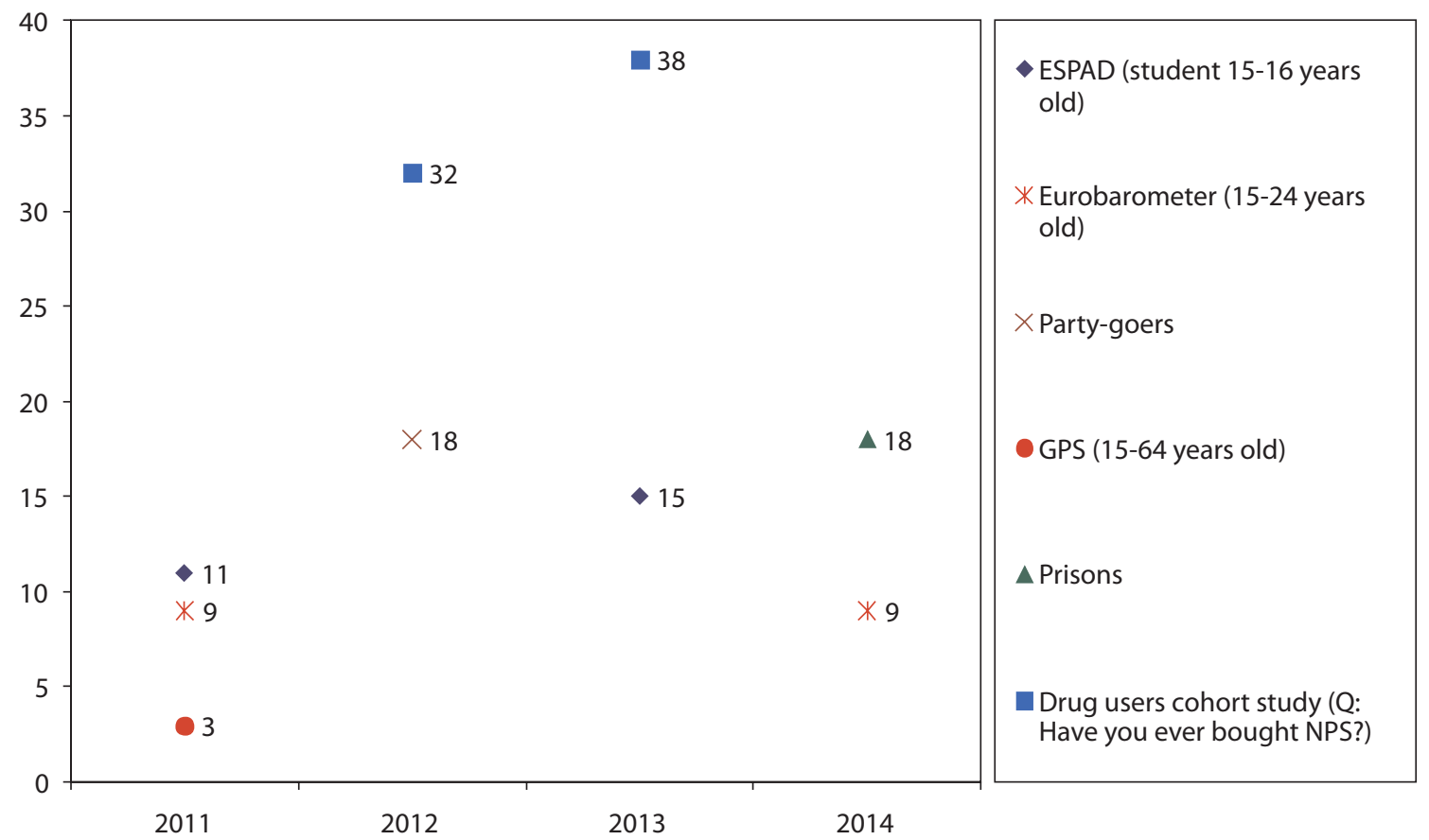

Fig. 2. Lifetime prevalence of NPS in general population and sub-populations, 2011-2014 (\%)

Source: Several sources were used to prepare this figure and words in survey questions, in most of the cases - "spice", "smoking mixture", ESPAD: ESPAD Report..., Group 2012; Trapencieris et al., 2013; Eurobarometer: Flash Eurobarometer 330...; Flash Eurobarometer 401 ...; Party-goers: Koroḷeva et al., 2012; GPS - General Population Survey: Sniķere et al., 2011; Prisons: Kḷave et al., 2014; Drug users cohort study: Trapencieris et al., 2014.

market, a more rapid tool - temporary ban - was introduced in the legislation.

- Temporary ban of NPS defines that the Centre for Disease Prevention and Control of Latvia may take a decision regarding imposing a ban or restriction for up to 12 months on the manufacturing, acquisition, storage, transportation, forwarding or distribution of NPS or their preparations that are not included in the lists of controlled substances in Latvia, but regarding which information has been received from the Early Warning System or a conclusion of a forensic expert institution regarding (Law on Procedures for the Legal Trade of the Narcotic and Psychotropic Substances).

In analogy this system treats NPS in the same way as illicit drugs - criminal liability for use, possession, smuggling, selling etc. foreseeing harsh sanctions. Practice also showed that in order to keep this system effective generic system must be updated regularly and temporary bans issued when necessary. By the end of 2015, there are 18 generic groups introduced, covering synthetic cannabinoids, cathinones, phenethylamines, amphetamines and other. In practice, the list is still being updated regularly - the latest amendments came into force in June 2015. As regards temporary bans, by April 2016 in total 35 bans have been issued.
Seemingly, that NPS market was closed or at least considerably suspended when in April 2014, due to the amendments in the Criminal Law, violation of the temporary ban became a criminal offence. When these amendments in came into force, all detected 43 "legal high" selling places were closed and, according the observation of the police, new ones have not been opened. Also some data on registered intoxication cases by emergency services might indicate that the number of acute health problems has decreased, for example, just before the closure of NPS market in March 2014 the number of acute drug intoxications (diagnoses F11-F19, intoxications of NPS not distinguished) reached 95 cases, but after the closure of NPS retail market in June 2014 the State Emergency service registered 34 intoxications with diagnoses F11-F19 (Sile, 2015). Data on latest sociological surveys on prevalence are not available yet.

In addition, the closure of the NPS market, taking into consideration that it has been significant in case of Latvia, could have brought some changes in the illicit drugs market, however analysis of it is still too early since the data for 2015 has not been collected. 


\section{Others countries}

Several countries of Central and Eastern Europe were selected for analysis. Poland and Latvia were especially targeted as those countries had the highest NPS use prevalence rates as the widest stationary distribution networks. It was worth comparing the situation in Latvia to the two other Baltic States. In the case of Poland, it was worth looking at the situation in Czechia where, after the closure of NPS stores in Poland, the new stores were emerging on the Polish-Czech border (Jabłoński, Malczewski, 2014). Romania and Hungary were also the countries particularly stricken with the NPS problem.

\subsection{Estonia}

Estonia seems to be a country where NPS market has not developed. Neither retail, nor internet sale has developed. Available data show that there have been few emergency cases related to synthetic cannabinoids (AB-CHMINACA), but in overall NPS use is quite low. In a study carried out in Narva city in 2014 among people who inject drugs, $4 \%(n=14)$ reported 3D (bath salts - alfa-PVP) use and one person reported the use of new psychoactive substances (e.g., Spice, PMMA, mCPP, BZP) (Vorobjov, 2015).

Even though the NPS prevalence is low, Estonia authorities regularly schedule new substances in their list of controlled substances with a decree of the Minister of Health and Social affairs. In 2013 a new schedule $V$ was introduced into the Narcotic and Psychotropic Substances Act ( Pugūle et al., 2015). Substances under this schedule are prohibited only if the intension or use is to cause human intoxication. In 2014, in total 21 substances was added to the V Schedule (Salekesin, 2015).

\subsection{Lithuania}

Also in Lithuania NPS market can be assessed as small. These substances are mainly sold via the Internet and in 2014 there were 40 such on-line shops identified. In 2015, an Omnibus survey was carried out and results showed that 3\% respondents have used NPS (Jasaitis, 2015a).

Lithuanian authorities also put efforts in their legislation in order to avoid development and in 2011 first generic group of cathinone derivatives and 6 groups of cannabinoid derivatives were introduced in the list. Since then this list is updated regularly and, for example, in 2013, five generic groups were modified and 58 individual substances scheduled, in 2014 - 25 substance scheduled. Moreover, the scheduling takes from 2 to 7 moths, which apparently is enough to keep the NPS market underdeveloped (Jasaitis, 2015b).

\subsection{The Czech Republic}

In the Czech Republic in 2010 there was a massive increase in the supply of NPS. In effect, the government decided to extend the list of narcotic and psychotropic substances by 33 new substances. Imports of new substances into the Czech Republic were reduced. In 2010, there were over 20 shops selling NPS. After April 2011 almost all of them were closed. NPS started to be available through the internet. In 2013: 19 e-shops with a Czech interface were identified (Grohmannova, 2013). The prevalence of NPS in Czech Republic is not high. The General Population Survey of 2011 showed the lifetime prevalence rate of 1.6\% (age group 15-64). One year later in the next survey the result was similar - 1.1\% (Mravčík et al., 2015). The peak of the NPS prevalence was reached in 2010/2011 when 20 and 50 shops respectively operated in the country (Běláčková, 2013). Mainly it was caused by the closure of the shops in Poland. As in Poland, the highest prevalence was noticed among clients of low threshold programs. According to the survey of 2013, among 1797 clients of such programs $11 \%$ used NPS (Grohmannova, 2013). The most popular group of NPS seems to be cathinones in 2014. According to the TOP-10 of the I-TREND project there were: 3-MMC, 4-FA (4-Fluoroamphetamine), 4-MEC, 6-APB, AMT, bk-MDMA (methylone), ethcathinone (ETH-CAT), MDPBP, methoxetamine (MXE), MPPP, penthedrone. The list of controlled substances has been updated twice in 2011 and 2015. The street shop NPS market ceased to exist. However, the NPS started to be available online. In May 2014, there were 30 active NPS online shops in the Czech Republic (Martinez et al., 2016).

\subsection{Hungary}

Between 2010 and 2014, NPS completely restructured the Hungarian drug market. Following the large-scale increase in the amount of mephedrone available in the summer of 2010, the proportion of the new psychoactive substances, as compared to the classical drugs, rose continuously. In 2014, the new substances constituted nearly $60 \%$ of police seizures (2015 National... Report, 2015). Out of the total 6509 drug-related offences registered in 2014, 347 offences (5.3\%) involved substances classified as new psychoactive substances according to the Hungarian law (2015 National... Report, 2015). The most frequent NPS types were cathinone derivatives, phenethylamines, synthetic cannabinoids and piperazine derivatives. In Hungary, there were few shops in 2010-2011. However, they were shut down $3 / 4$ years ago. It seems that retail NPS shops don't exist anymore. Online stores use mostly webpages. 


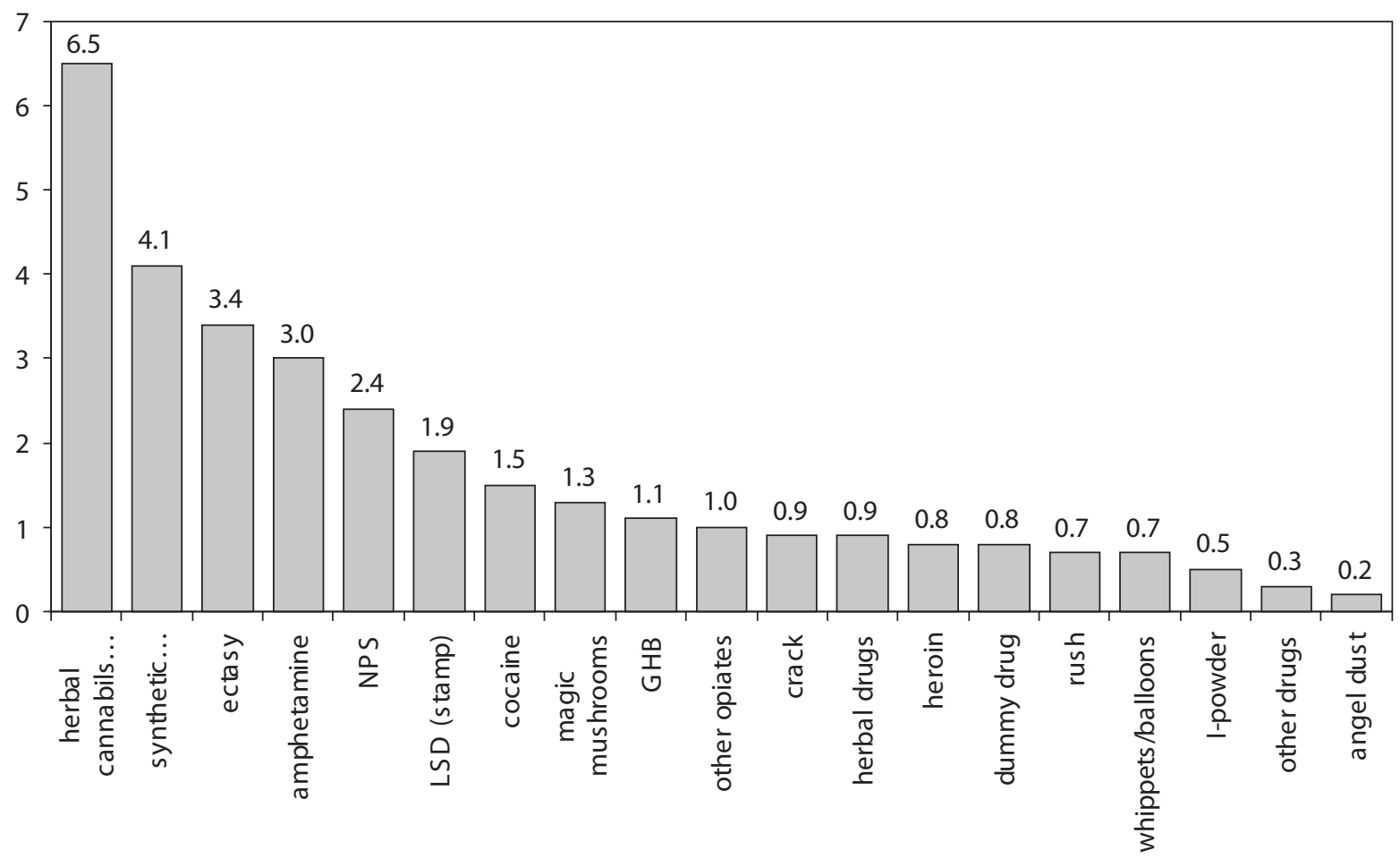

Fig. 3. Lifetime prevalence of different illicit drugs in the 19-64 age group in Hungary in 2013 (\%)

Source: 2015 National... Report, 2015.

NPS sales are done through dealers, which are one of the main sources of the supply. The prevalence of the NPS compared to other drugs seems to be relatively high. Any use of NPS in Hungary could be at the level similar to that of cannabis (Horvath: Hungarian Reitox Focal Point personal communication) (fig. 3). According to treatment data and data from needle/ syringe programmes NPS (synthetic cathinone) use is widespread among IDUs in Hungary. According to research data NPS (synthetic cathinone) use is also observed among OST clients (2015 National Report, 2015).. Increasing supply of NPS forced Hungarian decision-makers to elaborate a new monitoring and risk-assessment system, which can be used to provide the appropriate information for the making of responsible decisions on the control of NPS. Act XCV of 2005 (hereinafter: Medicines Act, Gytv.) lays down the framework of the new legislation, while Government Decree 66/2012 (IV. 2.) determines the process and persons responsible in connection with the reporting of new psychoactive substances, their preliminary specialist assessment, their scheduling and risk assessment. The Gytv. created the definition of "new psychoactive substance" as substances or groups of compounds recently appearing on the market that have no medicinal use and that, due to their effect on the central nervous system, are suitable for altering a person's state of consciousness, behaviour or senses, and therefore represent a threat to public health similar to the substances appearing in the illicit drug and psychotropic substance schedules, and so with respect to this, in the past the Government, currently the minister responsible for health, classified these as such materials in a decree. The Medicines Act and the Government Decree created a new schedule for the new psychoactive substances, which contains both individual compounds and compound groups (through this providing both a list of individual compounds and a generic approach) (2015 National Report, 2015). The Hungarian legal approach is based on generic and individual approach and includes risk assessment procedure.

\subsection{Romania}

Romania was one of the countries where there had been a rapid increase in the number of NPS shops. In 2010, 35\% of drug patients reported using NSP as primary drug. In 2011, Romania introduced solutions similar to the Polish ones such in the form of a wide definition of controlled NPS. The list of controlled substances has been updated twice in 2010 and 2014. In 2011, a new legislation package along with complex control measures of several institutions contributed to the closure of the NPS market. In 2011, the Joint order of several ministers and national authorities was issued. 33 new substances were added to the list and joint teams performed inspections of the locations in which NPS were 


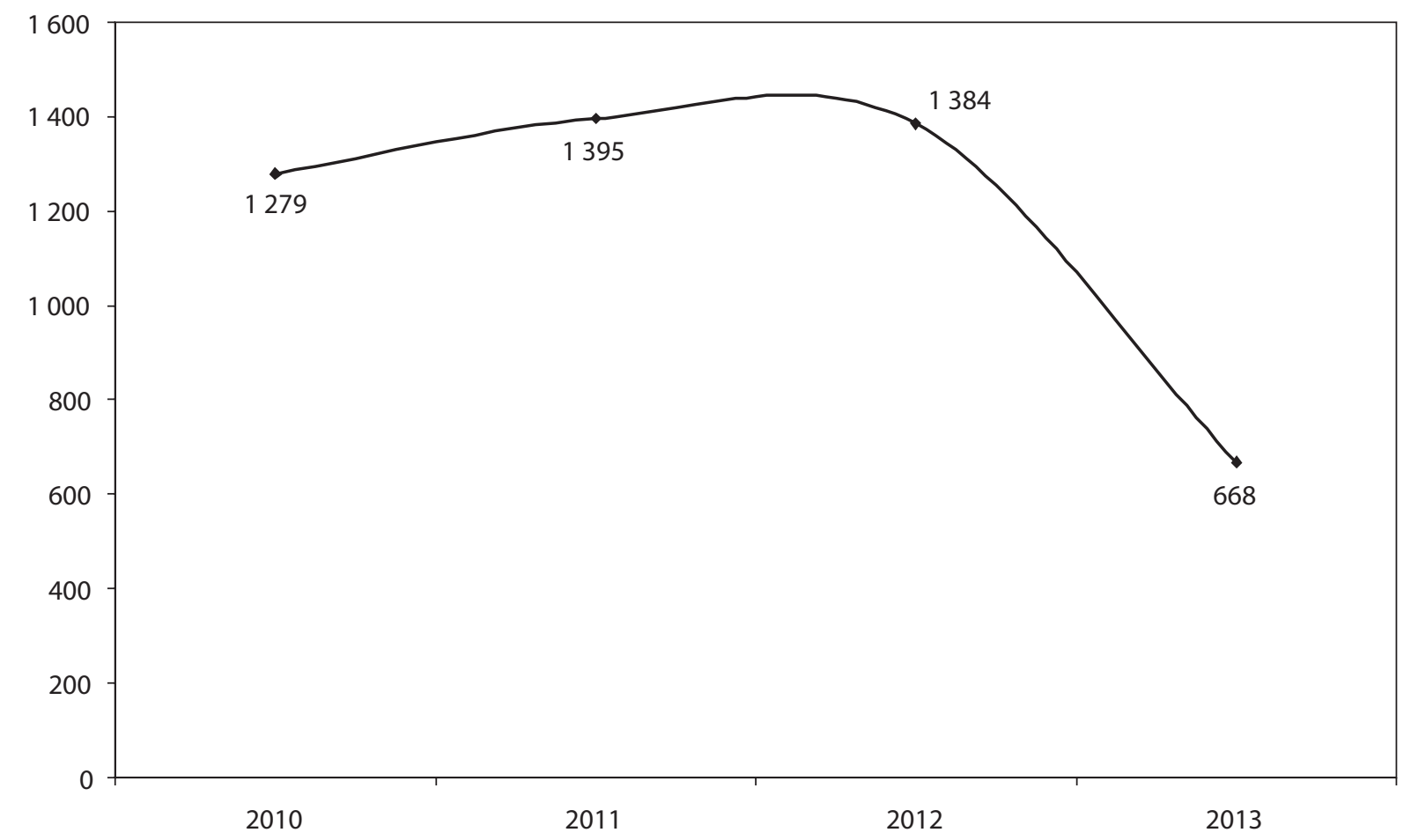

Fig. 4. Evolution of medical emergencies caused by NPS use, data compared 2010-2013 (number of cases)

Source: Gheorghe, 2014.

manufactured, sold or used, according to their field of expertise. In that year 867 locations, where NPS were likely to be sold, were inspected. A year later the number of shops halved to 442 (Gheorghe, 2014). In 2014, most probably synthetic cannabis was the main NPS on the market but in 2010/2011, they were synthetic cathinones. In 2011 (March), 158 retail outlets were closed (2012 National..., 2012). In 2015 , some online shops but not only focus on NPS. As a consequence of the measures taken in 2011 the retail shops were closed. The data in figure 4 show an increase in the number of poisonings following the closure of NPS shops and a decrease in poisonings in 2013. Among the drug patients in 2013 every tenth reported using NPS, which constitutes over a threefold drop compared to 2010 (Gheorghe, 2014).

\section{Findings}

Countries where problem reached the peak, the traditional response or simply substance scheduling did not work. Since the NPS do not fall under market regulations, also the response to the problem was innovative stepping out of the existing system (for example, temporary prohibition in Poland, Latvia, NPS list in Hungary, criminal liability or harsh sanctions in several countries, generic law in Latvia, Lithuania and Hungary). Moreover, a political and social pressure has been a factor to speed up the development of new regulations, sometime affecting the quality. Seemingly harsh sanctions and immediate reaction are main elements to close the NPS street shops. Meanwhile this approach hasn't caused a stepback for chemical industry or science. At the begging 2015 the retail market seems to be closed in Latvia and Romania but in Poland is developing because NPS distributor has been prepared to overcome new legislation again NPS market from 2011. Still is open question if national regulations against NPS market are fully enough. In case of drugs European countries are using UN convention as core document for controlling psychoactive substances. In case of NPS there are different approach and different substances are putting in the control in EU member countries. NPS market reacts very quickly for changing and only very strong and fast reaction from the institutional level seems to be effectiveness. According to the principle that every action is accompanied by a reaction, a decrease in the availability of NPS in NPS shops gave rise to a greater online supply, transferring the trade to the neighbouring countries (Czech Republic) or the arrival of more alternatives to controlled substances. Although NPS market differs in each country, study shows that harsh sanctions such as criminal liability and immediate reaction significantly decrease the availability of NPS, and thus contribute in decreasing acute health problems and prevalence. It was observed that at the time when stricter measure came into 
force, hospital emergencies were increased (Poland, Romania and in same extent Latvia).

\section{Reference}

2012 National Report (2011 data) to the EMCDDA by the Reitox National Focal Point, 2012, Romanian Reitox Focal Point, Bucharest.

2015 National Report (2014 data) to the EMCDDA by the Reitox National Focal Point, 2015, Hungarian Reitox Focal Point, Budapest.

Act XCV of 2005 on medicinal products for human use and on the amendment of other laws regulating the pharmaceutical market in Hungary (the amendment to the Act came into effect on the 1st of March 2012).

Běláčková V., 2013, New synthetic drugs in the Czech Republic - ways to get through survey methods, Presentation for REITOX Academy on New Psychoactive Substances, Warsaw, 5th September, 2013.

Brunt T., Atkinson A., Nefu T., Martinem M., Lahaie E., Malczewski A., Pazinty M., Belackova V., Brandt S., 2017, Online test purchased new psychoactive substances in 5 different European countries: A snapshot study of chemical composition and price, International Journal of Drug Policy, 44, 105-114. doi: 10.1016/j.drugpo.2017.03.006

Burda P., 2014, Raport o zgłoszonych przypadkach podejrzeń zatruć substancjami psychoaktywnymi (dopalaczami) (Eng. Report on reported cases of suspected poisoning with new psychoactive substances), Ośrodek Kontroli Zatruć, Warszawa.

Burda P., 2015, Raport o zgłoszonych przypadkach podejrzeń zatruć substancjami psychoaktywnymi (dopalaczami) (Eng. Report on reported cases of suspected poisoning with new psychoactive substances)), Ośrodek Kontroli Zatruć, Warszawa.

Early Warning System Database of EMCDDA, 2015, European Monitoring Centre for Drugs and Drug Addiction, Lisbon.

ESPAD Report 2011: Results from the European School Survey Project on Alcohol and Other Drugs, 2012, ESPAD Group, The Swedish Ministry of Health and Social Affairs and the European Monitoring Centre for Drugs and Drug Addiction (EMCDDA), Sweden.

European Drug Report 2015: Trends and Developments, 2015, European Monitoring Centre for Drugs and Drug Addiction, Publications Office of the European Union, Luxembourg.

Flash Eurobarometer 330: Youth attitudes on drugs, European Commission https://data.europa.eu/euodp/data/dataset/S1006_330 (data accessed: 10 January 2017).

Flash Eurobarometer 401: Young people and drugs, European Commission, https://data.europa.eu/euodp/data/dataset/S2029_401 (data accessed: 10 January 2017).

Gheorghe B., 2014, NPS in Romania. Romanian focal point on drugs and drug addiction, Presentation for the conference in Warsaw 2-3 October 2014.

Government Decree 66/2012 (IV. 2.) on activities related to narcotic drugs, psychotropic substances and new psychoactive substances, on scheduling of these substances and on modification of schedules (repealing Government Decree 142/2004 and Government Decision 1196/2009) (the Decree came into effect on the $3^{\text {rd }}$ of April 2012) and $\$ 283 / B$ of Criminal Code (the amendment to the Criminal Code came into effect on the 1st of March 2012).

Grohmannova K., 2013, NSD use among PDU. Czech National Monitoring Centre for Drugs and Drug Addiction, Presentation for Reitox Academy on New Psychoactive Substances 4-5 September 2013 Warsaw.

GSI, 2016a, information from General Sanitary Inspection http://gis.gov.pl/zdrowie/dopalacze/dane-statystyczne (data accessed: 06 March 2016).

GSI, 2016b, Official Information for Senat wrote by General Sanitary Inspection., Warsaw.

Jabłoński P., Malczewski A., 2014, New psychoactive substances: problem and response, National Bureau for Drug Prevention, Warsaw.

Jasaitis E., 2015a, NPS users profile: Lithuania case. Presentation for Reitox Baltic Academy in Cracow - Poland, 3-4 September 2015.

Jasaitis E., 2015b, NPS market and NPS in law: Lithuania perspective, Presentation for Reitox Baltic Academy in Cracow - Poland, 3-4 September 2015.

Kḷave et al ., 2014, Narkotiku lietošanas izplatība ieslodzijuma vietās Latvijā 2014.gadā. Pétījuma rezultāti (Eng. Prevalence of drug use in prisons in Latvia in 2014. Research results), Slimību profilakses un kontroles centrs, Rīga.

Koroḷeva I., Trapencieris M., Snikgere S., Kārklin,a I., Jankovskis M., Kriek̦e L., 2013, Narkotiku lietošanas izklaides vietāis 2012. gada (Eng. Drug use at the recreational setting in 2012), Slimību profilakses un kontroles centrs, Riga.

Malczewski A., 2014, Młodzież a substancje psychoaktywne (Eng. Youth and Psychoactive Substances), [in:] B. Grabowska (ed.), J. Kalka, R. Boguszewski, K. Kowalczuk, M. Feliksiak, M. Herrmann, B. Badora, M. Omyła-Rudzka, B. Roguska, M. Feliksiak, M. Gwiazda, A. Malczewski, Młodzież 2013 (Eng. Youth 2013), Fundacja Centrum Badania Opinii Społecznej, Warszawa, 154-173.

Malczewski A., 2015a, "Dopalacze" coraz bardziej niebezpieczne (Eng. New Psychoactive Substances getting more dangerous), Remedium, 9/2015, 24-25.

Malczewski A., 2015b, Drug market and crime workbook. Polish workbook for EMCDDA, National Bureau for Drug Prevention, Warsaw.

Malczewski A., 2016, Odbiorcy programów wymiany igieł i strzykawek - wyniki badania (Eng. Clients of needles and syringes programs - result of the survey), Remedium, 2/2016, 25-26.

Malczewski A., Misiurek A., 2015, Używanie narkotyków i “dopalaczy" w populacji generalnej (Eng. Using drugs and New Psychoactive Substances in general population), Serwis Informacyjny NARKOMANIA, 72, 32-37.

Malczewski A., Sałustowicz P., 2015, I-TREND - badanie dotyczące nowych substancji psychoaktywnych (Eng. I-TREND - New Psychoactive Substances survey), Serwis Informacyjny NARKOMANIA, 72, 18-21.

Martinez M., Kmetonyová D, Běláčková V., 2016, A method for exploring the number of online shops selling new psychoactive substances: initial I-TREND project results in: The 
internet and drug markets (European Monitoring Centre for Drugs and Drug Addiction: Insights 21), Publications Office of the European Union, Luxembourg.

Mravčík V., Běláčková V., Grohmannová K., Zábranský T., 2015, Nove psychoaktivni latky a jejich vyskyt v Česke republice (Eng. New psychoactive substances and their prevalence in the Czech Republic), Národní monitorovací středisko pro drogy a závislosti, Úřad vlády ČR, Časopis lékařů českých, 153 (5), 216-221.

New psychoactive substances in Europe: Legislation and prosecution - current challenges and solutions, 2016, European Monitoring Centre for Drugs and Drug Addiction and Eurojust, EMCDDA - Eurojust joint publication, Publications Office of the European Union, Luxembourg.

Pūgule I., Ābele I., Vanaga D., Sïle L., Pelne A., Lucenko I., ZīleVeisberga A., Trapencieris M., 2015, Situācija narkotiku un narkomānijas problēmas jomā latvijā līdz 2015. gadam (Eng. Situation in drug situation in Latvia until 2015), Slimību profilakses un kontroles centrs, Rīga.

Rychert M., Wilkins C., 2015, The challenge of a ban on animal testing for the development of a regulated legal market for new psychoactive substances (NPS) ('legal highs') in New Zealand: Issues and options for resolution, International Journal of Drug Policy, 26(12), 1273-1278. doi: 10.1016/j.drugpo.2015.08.006

Salekesin M., 2015, NPS market and NPS in law, Estonia, Presentation for Reitox Baltic Academy in Cracow - Poland, 3-4 September 2015.

Sierosławski J., 2015, Używanie substancji psychoaktywnych przez młodzież w 2015 roku ESPAD (Eng. Psychoactive Substances using by youth in 2015 ESPAD), Presentation from the press conference on 30 November 2015, KBPN, PARPA, IPIN. Warsaw.

Sïle L., 2015, Jaunās psihoaktīvās vielas Latvijā: Situācijas analize 2007-2014 (Eng. New psychoactive substances in Latvia: analysis of the situation between 2014 and 2017), Slimību profilakses in kontroles centrs, Rīga.

Snikgere S., Trapencieris M., Koroḷeva I., Mierina I., Priekule S., Aleksandrovs A., Jankovskis M., 2012, Atkarību izraisošo vielu lietošanas izplatība iedzivotāju vidū. Pētijuma rezultāti (Eng. Addictive substance use among the general population), Slimību profilakses in kontroles centrs, Rīga.

Trapencieris M., Pētersons A., Sniḳere S., 2013, Alkohola, tabakas un narkotiku lietošanas izplatība skolēnu vidū Latvijā. Metodologiskā pētijuma rezultāti (Eng. The prevalence of alcohol, tabaco and drug use among students: Methodological study,), Slimību profialkases un kontroles centrs, SIA "Socioloǵisko pētijumu institūts”, Rīga.

Trapencieris M., Snik̦ere S., Kaupe R., 2014, Narkotiku lietošanas tendences un paradumi Latvijā: narkotiku lietotāju kohortas pètijuma septītā posma (2013. gada) rezultāti (Eng. Drug use patterns and trends in Latvia: cohort study of drug users. The seventh phase). Biedrība "Dialogs", Rīga.

Vorobjov S., 2015, New psychoactive substances in Estonia, available data from recent surveys, Presentation for Reitox Baltic Academy in Cracow - Poland, 3-4 September 2015. 